\title{
Terrestrial implications for the maritime geoarchaeological resource: $A$ view from the Lower Palaeolithic
}

Article

Accepted Version

Hosfield, R. (2007) Terrestrial implications for the maritime geoarchaeological resource: A view from the Lower Palaeolithic. Journal of Maritime Archaeology, 2 (1). pp. 4-23. ISSN 1557-2285 doi: https://doi.org/10.1007/s11457-0079013-7 Available at https://centaur.reading.ac.uk/3636/

It is advisable to refer to the publisher's version if you intend to cite from the work. See Guidance on citing.

To link to this article DOI: http://dx.doi.org/10.1007/s11457-007-9013-7

Publisher: Springer

All outputs in CentAUR are protected by Intellectual Property Rights law, including copyright law. Copyright and IPR is retained by the creators or other copyright holders. Terms and conditions for use of this material are defined in the End User Agreement.

www.reading.ac.uk/centaur 
Central Archive at the University of Reading

Reading's research outputs online 
Author's Original Manuscript - Postprint

This is an Author's Accepted Manuscript of an article published as: Hosfield, R.T. 2007.

Terrestrial implications for the maritime geoarchaeological resource: a view from the Lower

Palaeolithic. Journal of Maritime Archaeology 2(1): 4-23.

ISSN 1557-2285; doi: 10.1007/s11457-007-9013-7 


\title{
Terrestrial implications for the maritime geoarchaeological resource: a view from the Lower Palaeolithic
}

\section{Dr Robert Hosfield}

Department of Archaeology, School of Human \& Environmental Sciences, University of Reading, Whiteknights, PO Box 227, Reading, RG6 6AB. E-mail: r.hosfield@rdg.ac.uk. Telephone: +44 (0)118378 7632 .

\begin{abstract}
Stone tools and faunal remains have been recovered from the English Channel and the North Sea through trawling, dredging for aggregates, channel clearance, and coring. These finds highlight the potential for a maritime Lower Palaeolithic archaeological resource. It is proposed here that any Lower Palaeolithic artefacts, faunal remains, and sediments deposited in the maritime zone during dry, low-stand phases were once (and may still be) contextually similar to their counterparts in the terrestrial Lower Palaeolithic records of north-western Europe. Given these similarities, can interpretive models and analytical frameworks developed for terrestrial archaeology be profitably applied to an assessment of the potential value of any maritime resource?
\end{abstract}

The terrestrial geoarchaeological resource for the Lower Palaeolithic is dominated by artefacts and ecofacts that have been fluvially re-worked. The spatio-temporal resolution of these data varies from entire river valleys and marine isotope stages to river channel gravel bar surfaces and decadal timescales, thus supporting a variety of questions and approaches. However, the structure of the terrestrial resource also highlights two fundamental limitations in current maritime knowledge that can restrict the application of terrestrial approaches to any potential maritime resource: (i) how have the repetitive transgressions and regressions of the Middle and Late Pleistocene modified the terrace landforms and sediments associated with the river systems of the English Channel and southern North Sea basins?; and (ii) do the surviving submerged terrace landforms and fluvial sedimentary deposits support robust geochronological models, as is the case with the classical terrestrial terrace sequences?

This paper highlights potential approaches to these questions, and concludes that the fluvial palaeogeography, Pleistocene fossils, and potential Lower Palaeolithic artefacts of the maritime geoarchaeological resource can be profitably investigated in future as derived, low-resolution data sets, facilitating questions of colonisation, occupation, demography, and material culture.

\section{Introduction}

The recovery of Palaeolithic stone tools and Pleistocene faunal remains from both the English Channel and the southern North Sea has a long, if rather poorly documented, history. Thousands of fossils have been collected from the southern North Sea, principally from the area between the Brown Bank and the Deep Water Channel but also 
from the Euro Channel approach to Rotterdam harbour (van Kolfschoten \& van Essen 2004: Fig. 9.4). Much smaller numbers of Middle Palaeolithic artefacts have been identified from deposits offshore of Cherbourg (Fermanville) and Holland (Zeeland), with handaxes being recovered from the latter location and Levalloiso-Mousterian artefacts from the former (Verhart 2004: 57-59 \& Fig. 7.3; Westley et al. 2004: 141). Other authors have also reviewed and discussed further material (the great majority of this being faunal remains) and the wider potential of the maritime zone (e.g. Flemming 1998, 2002; Hack 2000; Verhart 2001; Wenban-Smith 2003; Glimmerveen et al. 2004; Wessex Archaeology 2004; Westley et al. 2004; see also van Kolfschoten \& van Essen 2004 for additional references).

These discoveries continue to remind archaeologists that these maritime zones were dry terrestrial landscapes for significant portions of Pleistocene (and Holocene) time. This theme has been emphasised in recent years with regard to both the Palaeolithic (e.g. White \& Schreve 2000; Ashton \& Lewis 2002; Westley et al. 2004) and the early Mesolithic periods (e.g. Coles 1998; Fischer 2004). Moreover, both Coles (1998: 45) and Westley et al. (2004: 5-6) have stressed the status of these zones as landscapes of occupation during their dry phases, rather than simply as landbridges facilitating the migration of people and animals to and fro, between Britain and continental Europe. In combination with recent work emphasising the fluvial palaeogeography of the Channel River and its tributaries (e.g. Antoine et al. 2003; Bates et al. 2003; Gibbard \& Lautridou 2003; Lericolais et al. 2003; Reynaud et al. 2003) these studies have raised the possibility that there may be a significant Lower Palaeolithic maritime resource associated with, or derived from, fluvial deposits located under the sea-bed surfaces of the English Channel and the southern North Sea. To date however there have been no unequivocal finds of Lower Palaeolithic artefacts from these submerged areas. This paper takes the view that hominins would have been present in these 'landscapes' during low stand phases, in light of their documented on-shore presence (e.g. Roberts et al. 1995; Tuffreau \& Antoine 1995; Bosinski 1995), although it is recognised that occupation intensity may have been limited by the harsh climatic conditions associated with low sea levels at these latitudes (e.g. White \& Schreve 2000). The apparent absence of maritime artefacts therefore requires explanation: issues of sampling logistics and/or bias, and deposit preservation and/or modification will be returned to below.

The presence of an archaeological resource, whether in relatively large or small quantities, presents a number of problems linked to the processes of discovery, recovery, assessment, protection, and interpretation. As some of these issues have been dealt with elsewhere (e.g. Wenban-Smith 2003; Gupta 2004), this paper is primarily concerned with the issues of assessment and interpretation. As with its terrestrial counterpart, the assessment and interpretation of a Lower Palaeolithic maritime geoarchaeological resource in a meaningful manner requires a comprehensive understanding of the processes of assemblage formation and modification. Such processes would influence both primary context sites and secondary context findspots (and potentially even tertiary context artefacts). These processes define the spatio-temporal resolution of the data (e.g. Stern 1993, 1994, 2004; Hosfield \& Chambers 2005) and therefore provide guidance as to those questions which may profitably be asked of these data (e.g. Gamble 1996; Hosfield \& Chambers 2004; Hosfield 2005). 
The central premise of this paper argues that Lower Palaeolithic artefacts were deposited alongside fossil remains and fluvial sediments in the 'dry' maritime zones during periods of low sea level. This material is suggested to have been, at least initially (see comments below regarding re-working and tertiary contexts), similar in character to its terrestrial equivalents. In other words, the archaeological contexts were dominated by fluvial floodplain sediments, containing derived lithic and faunal material. These fluvial sediments were associated with the Channel River and its many tributaries, including the 'off-shore' extensions of extinct and modern on-shore rivers such as the Solent River and the Bytham, and the Thames, Rhine, Seine and Somme (Figure 1). This premise is grounded in the dominance of the terrestrial record by derived assemblages in fluvial sedimentary contexts (e.g. Bridgland 1994; Wymer 1999) and the contextual similarities of the records of southern Britain (e.g. Bridgland 1994; Roberts et al. 1995; Wymer 1999), northern France (e.g. Tuffreau \& Antoine 1995; Tuffreau et al. 1997), and northwestern Germany (e.g. Bosinski 1995). While the presence and considerable importance of the primary context components of the Lower Palaeolithic archaeological record is of course acknowledged here (e.g. Roberts \& Parfitt 1998; Ashton et al. 1998), this paper is principally concerned with the secondary context component. This is in light of its extensive on-shore distribution and the probable disturbance and modification of a significant proportion of the off-shore resource (for the potential off-shore presence and detection of in situ deposits see Gupta 2004).

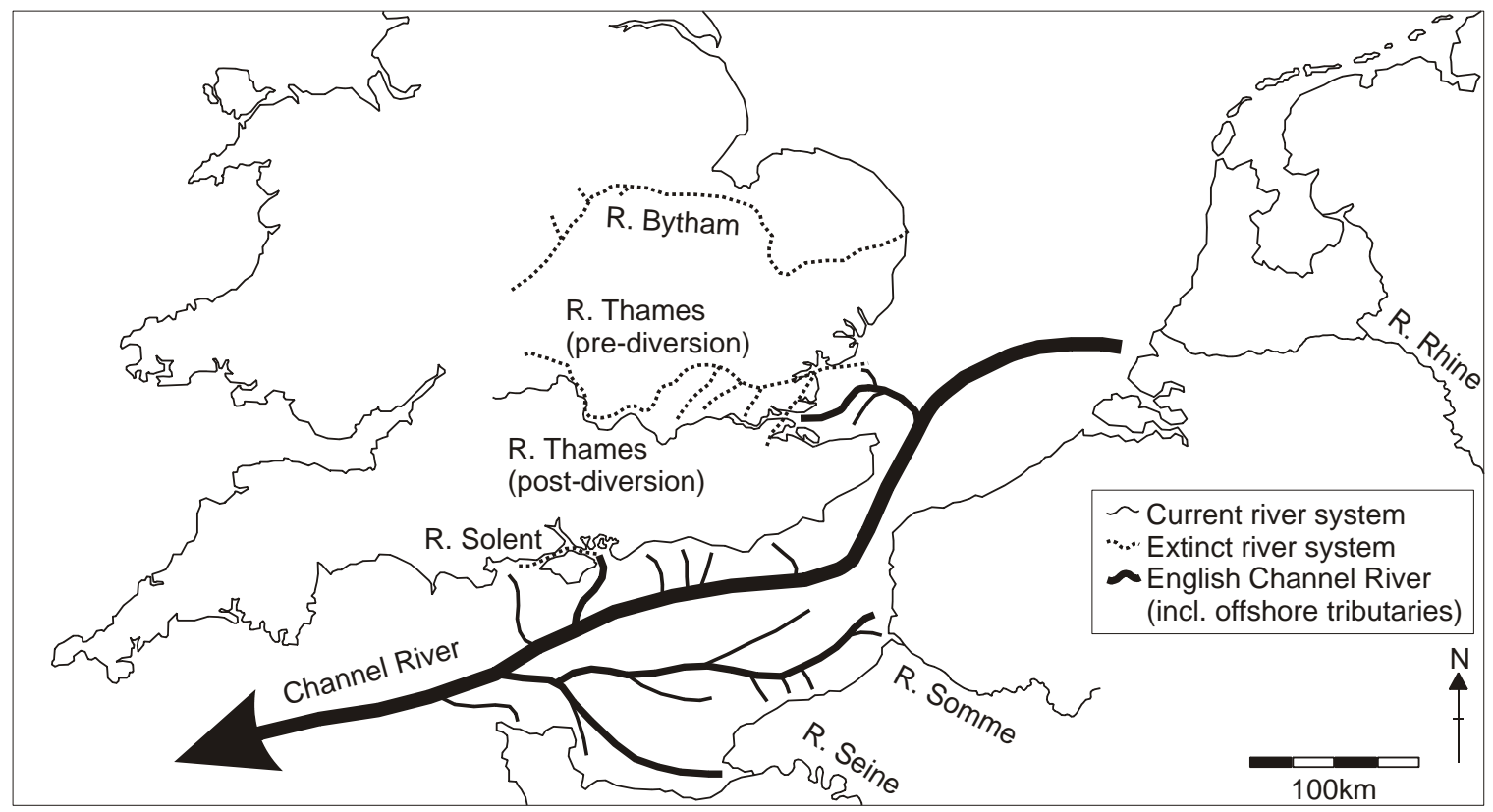

Figure 1: The English Channel River system and selected north-west European rivers during the last glacial (after Bridgland 2001: Fig. 3.5, Bridgland \& Schreve 2001: Fig. 1, Schreve \& Bridgland 2002: Fig. 2, and Roberts et al. 1995: Fig. 2)

In light of the proposed similarities between the on-shore and off-shore elements of the secondary context Lower Palaeolithic resource, it is suggested that frameworks developed for the interpretation of terrestrial material can be profitably applied to an assessment of the interpretative potential of off-shore materials. These frameworks are 
reviewed briefly below.

\section{A view from the land}

The terrestrial Lower Palaeolithic resource of north-western Europe is dominated by fragmented fluvial landscapes (terrace landforms and their sedimentary deposits), containing lithic artefacts and/or faunal remains (Figure 2). These artefacts frequently show evidence of physical damage (Figure 3), suggestive of derived origins and fluvial transportation, as in the assemblages from Dunbridge on the River Test (Chambers 2004), Broom on the River Axe (Marshall 2001; Hosfield \& Chambers 2004) and Warren Hill (Roe 1981) in East Anglia. The fluvial terrace sequences appear to have formed in response to broad and fine-scale palaeoclimatic fluctuations and isostatic and/or tectonic uplift (e.g. Vandenberghe 1995, 2002, 2003; Bridgland 2000; Maddy \& Bridgland 2000; Maddy et al. 2001; Antoine et al. 2003). It is also apparent that these fluvial terrace landforms and sequences have been subjected to significant erosion over the course of Pleistocene time, through sub-aerial activity and fluvial incision and downcutting. The Lower Palaeolithic resource therefore presents a number of interpretive difficulties (Hosfield \& Chambers 2004):

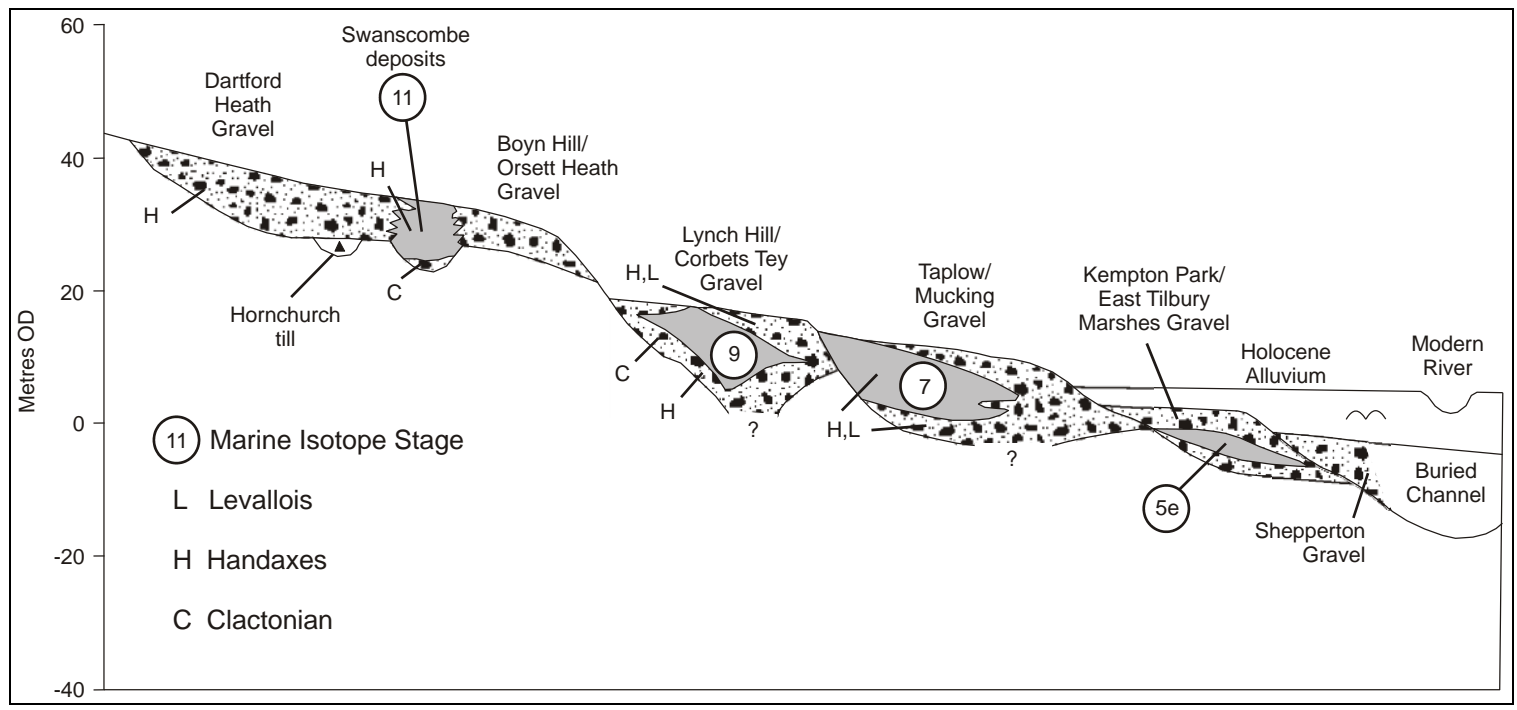

Figure 2: Terrace landforms, sedimentary deposits and lithic artefact distributions in the Lower Thames valley (after Bridgland 1998: Figure 5.4)

1. How old are the terrace sediments?

2. Over how long a period were the terrace sediments deposited?

3. Does the archaeological debris represent a chronologically homogeneous sample (i.e. is it the product of a 'single' behavioural episode) or a time-averaged archaeological palimpsest?

4. Is the archaeological debris the same age (or ages) as the sediments, or older (and if the latter, how much older)?

5. Did the archaeological debris originally accumulate on the landscape (e.g. through hominin tool discard and/or animal mortalities) at its place of discovery, or has it been re-worked downstream and/or downslope? 


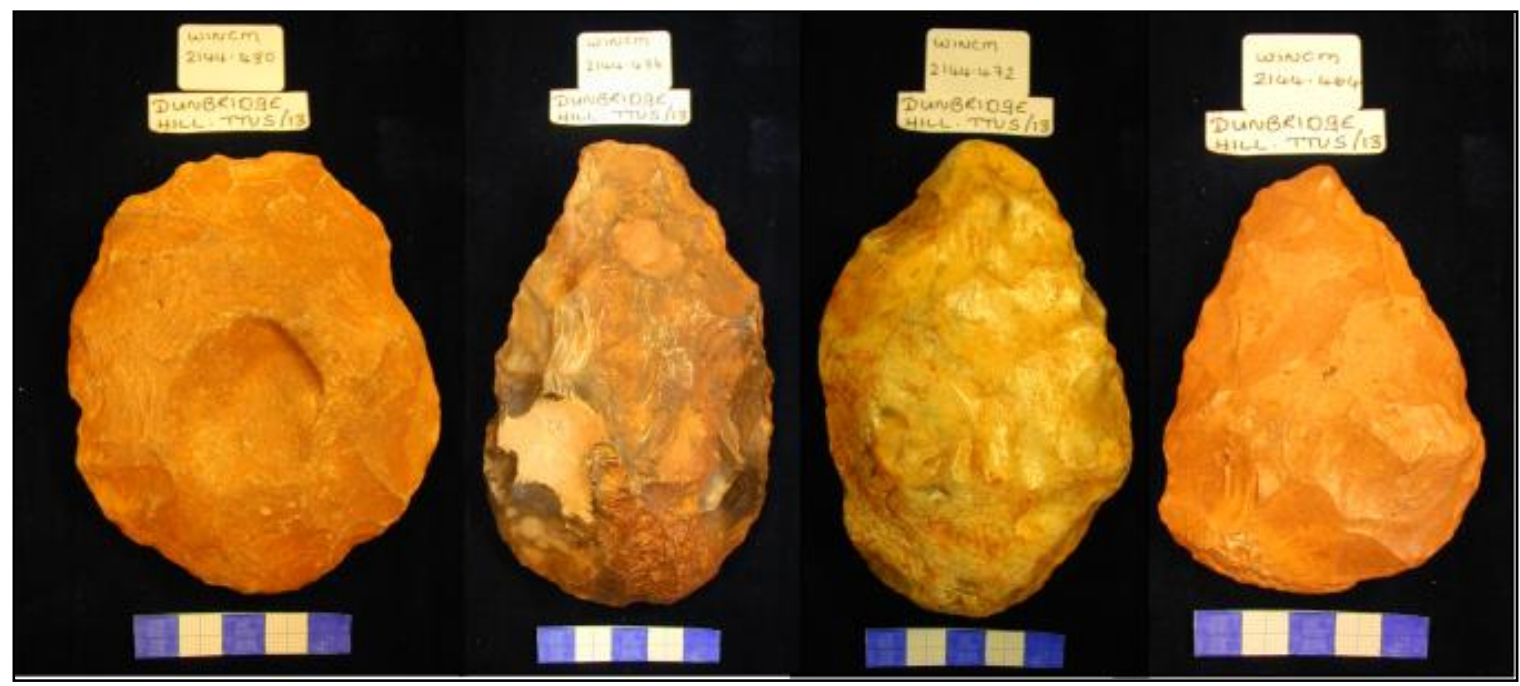

Figure 3: Sample of fluvially re-worked (transported and modified) handaxes from Dunbridge, Hampshire (@ Dr J.C. Chambers)

All of these interpretive problems relate to the spatio-temporal resolution of the data. They are therefore fundamental to the extraction of meaningful archaeological information (e.g. spatial and chronological patterns). Much of the early work undertaken on the secondary context Lower Palaeolithic resources of north-western Europe emphasised chrono-stratigraphic dating and the identification of broad typological groupings (e.g. Breuil 1939; Breuil \& Koslowski 1931, 1932, 1934; Roe 1968, 1981; Wymer 1968, 1974). To a large extent this reflected the absence of absolute dates for the fluvial terrace deposits and the need to develop broad-scale Palaeolithic chronologies. However it may in some instances have also highlighted attitudes regarding the quality of the resource and its limited usefulness.

The advent of absolute dating methods for the Middle Pleistocene saw the widespread rejection of evolutionary models of typo-technological refinement in the 1980s and early 1990s, with key evidence including the 'refined' ovate handaxes from Boxgrove at c. 500 kya (Roberts \& Parfitt 1998) and the 'crude' artefacts from Pontnewydd Cave at c. 200 kya (Green 1984). The last fifteen years has also seen considerable attention paid to the secondary context resource. This has included data collation and mapping on the one hand (e.g. Wessex Archaeology 1993a, 1993b, 1994, 1996a, 1996b, 1996c, 1997), and behavioural analysis and interpretation on the other. To some extent the latter has principally focused on the better contextualised material (e.g. Conway et al. 1996; White 1998a, 1998b; Ashton et al. 1998; White et al. 2006; Ashton et al. 2006), although some studies have also utilised regional data sets including assemblages with limited provenancing (e.g. Ashton \& Lewis 2002; Hosfield 2005).

During the last few years there have been major advances in optically stimulated luminescence dating (e.g. Duller et al. 1999; Agersnap-Larsen et al. 2000; Murray \& Wintle 2000; Yoshida et al. 2000; Wallinga et al. 2001; Murray \& Olley 2002; Toms 2002; Wallinga 2002; Bailey 2003; Bailey et al. 2003; Galbraith et al. 2005; Bateman et al. 2003; Thomsen et al. 2005) and amino-acid dating (Sykes et al. 1995; Kaufman \& 
Manley 1998; Penkman 2005). These developments have greatly increased the potential for direct, absolute dating of fluvial terrace sediment deposits (e.g. Lewis \& Maddy 1999; Hosfield \& Chambers 2002; Briant et al. 2006; Toms et al. 2005). This potential for dating the terrace sequences independently of their archaeological content has provided an opportunity to ask an expanded range of questions of the lithic artefacts and/or faunal assemblages. However, asking such questions require archaeologists to deal with the processes of derivation, deposition and re-working outlined above: principally, the questions of how far the material has been transported and how much older than the sediments the archaeology is.

The issues of re-working have been highlighted for fluvial terrace and floodplain deposits with respect to bedrock geology and river type by Bridgland (1985) and Howard \& Macklin (1999) respectively, while Hosfield (2001) has proposed models of secondary context assemblage formation. Following on from these studies, recent work by the author (see Hosfield \& Chambers 2004: Ch. 7 for a full discussion of these factors) developed new models of secondary context assemblage formation and explicitly addressed the spatio-temporal resolution of the data. Five key factors were emphasised:

1. River zone type: reflecting the differential geomorphological behaviour and preservation potential of fluvial systems in their upland and lowland stretches (following Howard \& Macklin 1999) it is apparent that the degree of re-working is likely to decrease markedly between the upland and perimarine/lowland zones (the latter of which are likely to be characteristic of both the Channel River and its tributaries).

2. Regional and local bedrock factors: following Bridgland (1985), Allen \& Gibbard (1993) and Hosfield (2001) it is clear that even within a particular river zone (e.g. the lowland zone of the Thames Basin) terrace preservation can vary markedly, ranging from terrace flights or 'staircases' to terrace-free 'gorges'. Such variability will again influence the potential scope for artefact re-working over relatively short (e.g. sub-MI stages) and long (e.g. multiple-MI stage) timescales. This factor highlights the importance of solid geology data in the interpretation of maritime materials, alongside Quaternary deposit and seabed sediment mapping (Long et al. 2004).

3. The 3-dimensional position of assemblages within the fluvial floodplain landscape: Devensian, Lateglacial and Holocene studies of channel plan-forms, floodplains, and fluvial migration activity (e.g. Rose et al. 1980; van Huissteden et al. 2001; Gibbard \& Lewin 2002) have emphasised both the complexity of channel structures, the rapidity of change within periglacial and Holocene river systems, and the potential for rapid re-working of artefacts and sediments.

4. The timing of the initial artefact depositional events across a glacial/interglacial cycle: existing models of fluvial systems over glacial/interglacial cycles (e.g. Bridgland 2000; Maddy et al. 2001; Gibbard \& Lewin 2002; Vandenberghe 1993, $1995,2002,2003)$ indicate marked variations in the nature and magnitude of fluvial activity. They also emphasise the association of fluvial activity phases with periods of 
climatic instability. Glacial/interglacial cycles may therefore influence the potential scope for artefact re-working over MI and sub-MI timescales.

5. Lithic artefact condition: new experimental research by Chambers (2004, 2005a, 2005b) and Hosfield \& Chambers (2004) has indicated the development of diagnostic damage patterns resulting from fluvial transportation.

These models and variables permit the consideration of the key issues of data resolution (e.g. is an assemblage more likely to represent a $100 \mathrm{kyr}$ palimpsest or a $5 \mathrm{kyr}$ palimpsest? Is it more likely to have been derived from a $20 \mathrm{~km}$ river catchment or a $2 \mathrm{~km}$ catchment?). More importantly such considerations enable the explicit mapping of data scales against different analytical approaches and archaeological questions (Table 1). For example, Ashton \& Lewis (2002) have utilised regional, derived artefact data from the Middle Thames fluvial landscape to track variations over time in artefact density. They used the Thames terraces as individual chronological units and the artefact data as a proxy to model possible population fluctuations. By contrast, Hosfield (2005; Hosfield \& Chambers 2004) utilised locally derived handaxes from Middle Pleistocene fluvial deposits at Broom on the River Axe (Devon/Dorset, UK) to model sub-MI stage trends in stone tool production.

\begin{tabular}{|c|c|c|c|}
\hline & & \multicolumn{2}{|c|}{ Chronological Resolution } \\
\hline & & MIS (e.g. $10^{4-5}$ years) & MI sub-stages (e.g. $10^{3-4}$ years) \\
\hline \multirow{2}{*}{ 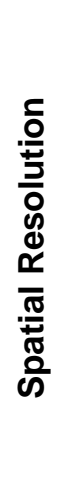 } & 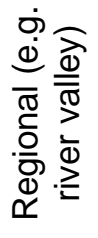 & $\begin{array}{c}\text { Population modelling (e.g. } \\
\text { Ashton \& Lewis 2002) }\end{array}$ & \\
\hline & 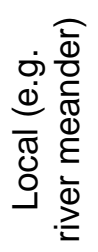 & & $\begin{array}{l}\text { Assemblage characterisation (e.g. } \\
\text { Hosfield 2005); Raw material } \\
\text { procurement strategies (e.g. White } \\
\text { 1998a); Occupation histories \& } \\
\text { technological change (e.g. White \& } \\
\text { Schreve 2000) }\end{array}$ \\
\hline
\end{tabular}

Table 1: Selected mapping of archaeological questions and approaches against variableresolution data sets

\section{The maritime resource}

Having reviewed analytical models and frameworks appropriate to derived, secondary context archaeology, what is the evidence for the Lower Palaeolithic in the maritime zone? It should first be noted that large areas of the central and northern North Sea have undergone extensive glacial erosion, with these processes at least part-explaining the extremely limited resource from those regions (Westley et al. 2004: 99 \& 143). However, the evidence from both the English Channel (particularly the Solent) and the southern North Sea encompass lithics, faunal material and pollen (Glimmerveen et al. 2004; Verhart 2004; van Kolfschoten \& van Essen 2004; Wessex Archaeology 2004). Although the vast majority of the archaeological material that has been recovered, principally 
through trawler fishing, consists of fossil bones, this paper adopts the view that the archaeological evidence for the Lower Palaeolithic occupation of Europe incorporates both traditional lithics and palaeoenvironmental materials.

Although the exact quantities are unknown, the faunal resource is clearly very substantial. In the southern North Sea between the UK and the Netherlands for example, fossil bones have been brought ashore since at least 1874, yielding some 7,500 specimens of Mammuthus primigenius alone in the National Museum of Natural History at Leiden (Glimmerveen et al. 2004: 43). Drees (1986) documented 54 locations in the southern North Sea which had yielded at least 100 fossil bones. It is also clear that different areas of the maritime zone have yielded palaeontological remains of varying Pleistocene ages. For example, the Brown Bank and Eurogeul localities have yielded Late Pleistocene fauna (Glimmerveen et al. 2004: 44-46), while outcrops of the Yarmouth Roads Formation to the east of the Deep Water Channel have provided fossils of Early to Middle Pleistocene age (van Kolfschoten \& van Essen 2004: 72-73).

The maritime faunal collections are therefore not all of Lower Palaeolithic age, and the best represented period is the Late Pleistocene (van Kolfschoten \& van Essen's (2004: 75-77) terrestrial association III). The materials most likely to be associated with lithic artefacts of Lower Palaeolithic period are van Kolfschoten \& van Essen's (ibid: 75-77) late Early Pleistocene/early Middle Pleistocene terrestrial association II. Van Kolfschoten \& van Essen (ibid: 76) have suggested that this association does not represent a single fauna of contemporary species, given the contrasting forest and steppe habitat preferences of two of the species (Mammuthus meridionalis and Mammuthus trogontherii respectively). Nonetheless Cameron et al. (1984, 1989a, 1989b) have demonstrated that only specific North Sea formations (the Yarmouth Roads Formation, the Brown Bank Formation, and the Kreftenheye Formation) yield fossil vertebrate remains, and only in those areas where these formations outcrop. The distributions of these formations should therefore provide a clear guidance to the development of sampling (and potentially protection) strategies associated with this resource. A key question however is whether further faunal associations can be identified in future which will bridge the key (from a Lower Palaeolithic perspective) chronological gap between association II (late Early/early Middle Pleistocene) and association III (Late Pleistocene). Such identifications might perhaps following the interglacial mammal assemblage zones of Schreve (2001), particularly in light of the apparent correlations between the UK and German Middle Pleistocene mammalian biostratigraphies (Schreve \& Bridgland 2002). Finally, it should also be noted that association II is relatively close in age to the recently reported c. 700 kya material from Pakefield, Suffolk (Parfitt et al. 2005; Roebroeks 2005), and that many of the species listed for this association have been recorded from the West Runton Freshwater Beds (van Kolfschoten \& van Essen 2004: 77).

The evidence for lithic material of Pleistocene age in the maritime zone is far less substantial than that for the fossil bone material, but small numbers of artefacts are nonetheless present. This has been clearly demonstrated for the global Lower Palaeolithic by the recent discovery of three Acheulean handaxes in $8 \mathrm{~m}$ of water, in Table Bay, South Africa (Flemming 1998; Werz \& Flemming 2001). With specific reference to the English Channel and southern North Sea regions, as stated earlier there are to date no clear 
examples of Lower Palaeolithic artefacts. There are however examples from the Middle Palaeolithic. In 1999 flint artefacts were collected from debris heaps (the product of shellfishing close to the Dutch coast), comprising of flakes, blades, cores, handaxes and one scraper (Verhart 2001, 2004). The surface weathering of the artefacts, the nature of the lithic technology, and the presence of the handaxes were all taken as indicating a Middle Palaeolithic age for the materials. Levalloiso-Mousterian tools dating to $c$. 45 kya have been found at Fermanville, Cherbourg, eroding out of peat deposits (which formed the side of a gully, interpreted as a submerged stream bed) $25 \mathrm{~m}$ below the surface (Westley et al. 2004: 141; Flemming 1998, 2002). Fishing activity in the Solent (Wessex Archaeology 2004) has also yielded extensive collections of lithic artefacts, of which at least some are of potential Pleistocene age, although personal observation of some of these collections by the author in 1997 suggested that the majority very probably date to the Mesolithic and Neolithic. One of the difficulties is of course the undiagnostic nature of much lithic material from the Palaeolithic period, but the Middle Palaeolithic handaxe finds do indicate the potential for the recovery and identification of Lower Palaeolithic artefacts. Moreover the increasingly robust evidence for chronologically diagnostic artefacts in the Lower Palaeolithic of the UK (including twisted ovate handaxedominated assemblages in MIS-11 (White 1998b) and the first appearance of Levallois technology in late MIS-9/early MIS-8 (Bridgland et al. 2006)) also offers potential for the recovery and identification of chronologically specific material.

Sediments recovered from the Eurogeul locality have also yielded pollen samples of Late Pleistocene (Weichselian) and Holocene age (Glimmerveen et al. 2004: 49-50). As with the Middle Palaeolithic lithic evidence these palynological samples certainly highlight the potential for the recovery of Lower Palaeolithic pollen material from appropriately aged Middle Pleistocene samples in the maritime zone, although no such materials have yet been recovered.

Finally, it is evident from the faunal and pollen evidence that these maritime zones were, for significant periods of the Middle Pleistocene, a potentially habitable landscape (and not simply a corridor for movement between the UK and the continent). Reconstructions of the palaeogeography of the English Channel 'landscape' (Antoine et al. 2003) suggest a palaeo-landscape characterised by extensive river systems (the Channel River and its tributaries) with wide river valleys and floodplains. Such habitats may well have been attractive to Middle Pleistocene hominins, despite the colder climates associated with low sea levels, and their place within the Lower Palaeolithic landscapes of north-western Europe is worthy of greater consideration.

\section{The maritime resource: gaps in our knowledge?}

Yet how should any potential Lower Palaeolithic maritime zone resource be interpreted? The likely nature of the resource (secondary or even tertiary context assemblages, distributed over an extensive spatial and chronological range) and the current methods of recovery and collection (coarse-grained sampling through dredging) will always produce an archaeological palimpsest, of relatively low spatio-temporal resolution. Such a resource is certainly challenging, yet I suggest that the types of models and approaches described earlier above can be applied to the interpretation of the secondary (if not 
always the tertiary) context material. This is principally because those models make an explicit link between the questions being asked and the data scales and resolutions that characterise the data (Tables $1 \& 2$ ). An immediate comparison can be made for example between the spatial scales of the Middle Thames fluvial landscape (the basis of the Ashton \& Lewis (2002) model) and identified dredging areas in the English Channel and the southern North Sea (Figure 4). The dredging areas to the immediate east of the Isle of Wight provide multiple sub-regional sampling units for exploring the archaeological signatures of the off-shore Solent River. Such comparisons implicitly acknowledge the spatial limitations of data provenancing with regard to dredged artefact material, but also highlight the value of questions addressing regional patterns in spatial palimpsest data sets. These questions can for example explore inter-regional comparisons of artefact data in terms of types and/or quantities of material.

\begin{tabular}{|c|c|c|c|}
\hline & & \multicolumn{2}{|c|}{ Chronological Resolution } \\
\hline & & Multiple-MIS (e.g. $10^{5-6}$ years) & MIS (e.g. $10^{4-5}$ years) \\
\hline \multirow{2}{*}{ 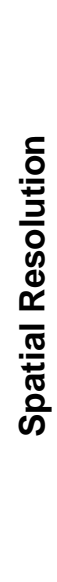 } & 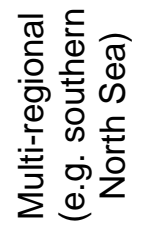 & Presence/absence & $\begin{array}{l}\text { Occupation intensity; } \\
\text { Typological patterning }\end{array}$ \\
\hline & 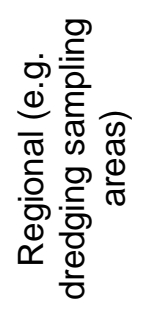 & $\begin{array}{c}\text { Presence/absence; Regional } \\
\text { variations }\end{array}$ & $\begin{array}{c}\text { Population trends; Typological } \\
\text { patterning }\end{array}$ \\
\hline
\end{tabular}

Table 2: Selected mapping of potential archaeological questions and approaches against variable-resolution data sets for a maritime Lower Palaeolithic resource

However, exploring these types of applications and approaches also highlights two major gaps and limitations in current knowledge:

\subsection{Maritime terraces?}

Firstly, investigations into the nature of fluvial terrace formation in the maritime zone and the impacts that the repeated transgressions/regressions of the Middle Pleistocene have had upon those terrace landforms and sediments are by no means complete. Two questions are particularly critical with regards to the geoarchaeological resource:

1. Do Middle Pleistocene terrace landforms and their associated deposits survive with their sedimentary architecture at least partially unmodified, or has everything been reworked into new fluvial architectural elements dating to more recent low sea-level stand events (e.g. the Last Glacial Maximum at $c$. 18,000 years ago)? Such re-working was reviewed by Westley et al. (2004: 93) with regards to the potential for tertiary contexts in the maritime record. These were defined as secondary contexts formed in a terrestrial 
environment which had subsequently been modified and re-worked during and after transgressive episodes. It was concluded that since multiple transgressive episodes have occurred over the course of the Pleistocene there is clearly potential for significant reworking of what were originally secondary context assemblages (see Westley et al. ibid: 176-195 for further details, including issues of sediment erosion, transport, and deposition). Westley et al. (ibid.) also noted that although the south coast of England is characterised by uplift activity (a key factor in terrace formation and evidenced both by the Solent River terraces and the Sussex raised beach sequence (e.g. Allen \& Gibbard 1993; Bates et al. 1997; Bridgland 2001; Bates 2001)), investigations to date have produced relatively little evidence for river terraces within the English Channel sediments. They suggest that this paucity is most pronounced in the larger palaeovalleys such as the Lobourg Channel and the Northern Palaeovalley (Westley et al. 2004: 135). This has been attributed by Hamblin et al. (1992) to destruction and re-working during subsequent high sea level transgressions. In other areas however net subsidence resulting in stacked sequences of deposits (decreasing in age upwards) may explain the absence of terrace landforms and their deposits (Bridgland 2000: 1297). 


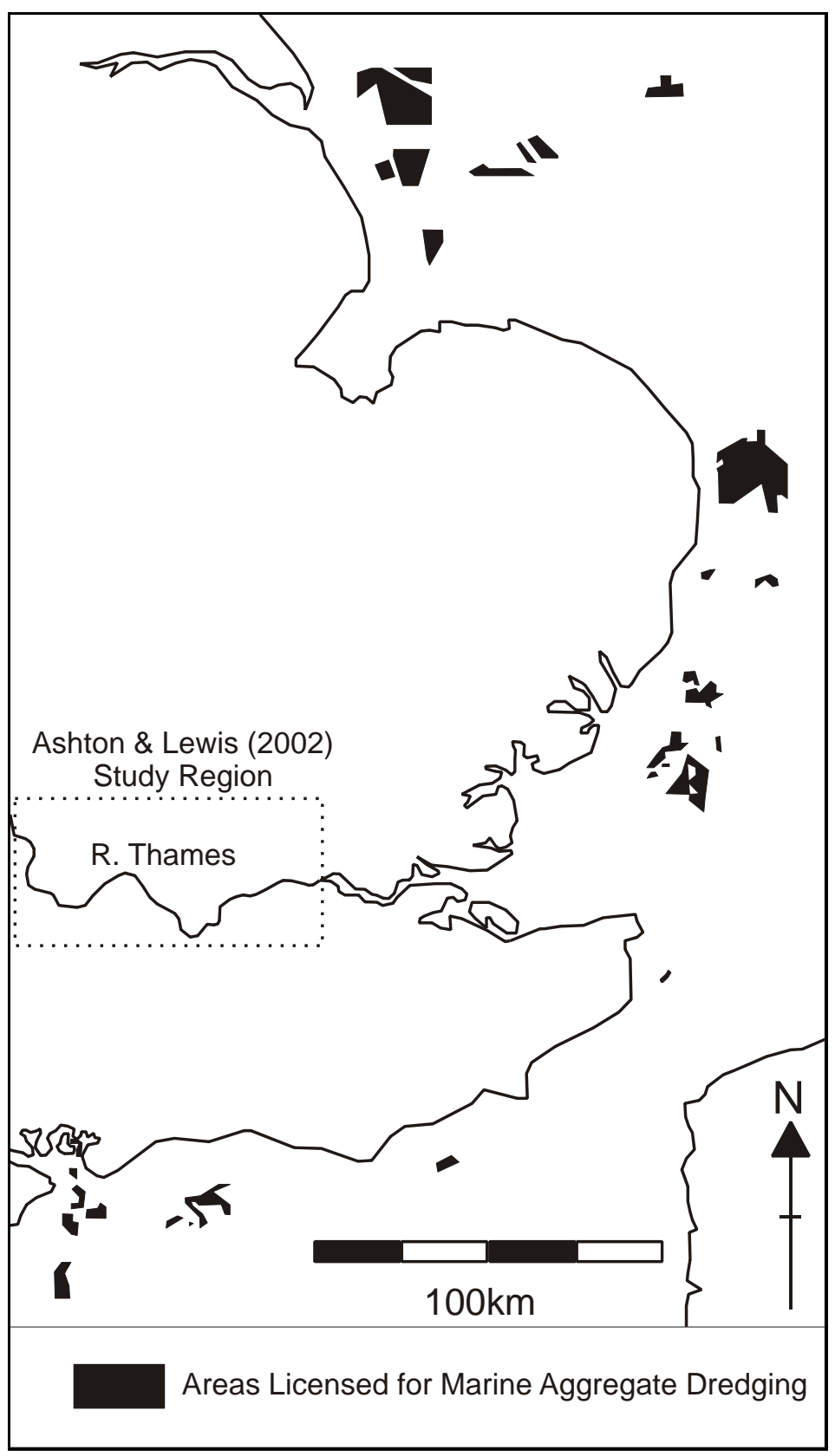

Figure 4: Spatial scales of licensed marine aggregates deposits (after Wenban-Smith 2003:

Figure 1) in the English Channel and southern North Sea, and Ashton \& Lewis' (2002: Figure 1) Middle Thames study region

However, other work on both sides of the English Channel and from the southern North Sea suggests that in places there are preserved landforms and deposits of Pleistocene age. Antoine et al. (2003) have mapped the large palaeovalley of the Seine, with its stepped terraces, beneath the modern Channel. Bellamy (1995) has recorded cold and warm stage terrace deposits and an infilled valley complex representing the offshore extensions of the River Arun and spanning at least three climatic cycles (see also Bridgland 2002: 27). Aggradations of a pre-Holocene interglacial, probably the Ipswichian, were recorded, 
along with both preceding and subsequent cold stage gravel aggradations and overlying Holocene estuarine sediments. Offshore buried channels have also been recognised in the East Solent (Velegrakis et al. 1999), while in the North Sea region, the British Geological Survey (Cameron et al. 1984, 1989a, 1989b) have mapped a series of formations of Pleistocene age. Indeed Cameron et al. (1992) have suggested that with the exception of the gravel waves between the South Falls and the Sandettie Banks, the majority of the Pleistocene fluvial (and glacial) gravel deposits in the southern North Sea have not been re-worked to a significant degree, despite the presence of strong tidal currents. From a Lower Palaeolithic archaeology perspective therefore, there appears to be some evidence for preserved Middle Pleistocene terrace deposits. It is stressed however that in many instances the degree of erosion is poorly known and the geochronological controls are poor in comparison to the current terrestrial situation.

Two approaches are suggested here as starting points for accessing these issues. Firstly, the application of optically stimulated luminescence dating to surviving fluvial sediments. This has been demonstrated by Stokes et al. (2003) for Late Pleistocene sediments, and adopted recently by Wessex Archaeology (Firth pers. comm.), although their preliminary results were unsatisfactory. Secondly, evaluating the physical condition of dredged artefacts. Chambers (2004, 2005a, 2005b) has proposed that fluviallytransported handaxes display diagnostic patterns of damage. If artefacts re-worked on the sea-bed (as a result of transgression/regression events) display different (non-fluvial) diagnostic damage patterns, then physical condition could be used as a partial indicator of taphonomic history. For example whether the dredged artefacts were recovered from preserved Middle Pleistocene-age terraces (showing fluvial-type damage signatures) or from 'modern' re-worked sediments (in which case marine-type damage signatures would be expected). This approach obviously requires programmes of experimental work, and results could also be evaluated against the material collected from sites such as Rainbow Bar, Hill Head in the Solent (e.g. Roe 2001; Hack 2000), where flake and core artefacts of variable status have been subjected to both fluvial and marine modification. Such work should also be integrated with current understanding of marine taphonomic processes, principally sediment dynamics. These processes have clear implications for the distribution (including the degree of 'patchiness' and size sorting) of re-worked archaeological material (see Westley et al. 2004: 176-195 for a review).

2. Even if Middle Pleistocene terraces and sediments are preserved however, is there evidence for classical terrace staircase sequences? As illustrated for example in the terrestrial extents of the Thames and Somme valleys (e.g. Breuil 1939; Bridgland 1994; Bridgland et al. 2004), such sequences are increasingly providing the basis for robust, geochronological models (e.g. Bridgland et al. 2006). As discussed above there is evidence for stepped terraces in the offshore palaeovalley of the Seine (Antoine et al. 2003). Similarly, Durrance $(1969,1974)$ has documented distinct river terrace sequences associated with the Teign estuary (at $-10.0 \mathrm{~m},-14.0 \mathrm{~m}$ and $-23.0 \mathrm{~m}$ ) and the modern Exe estuary (at $-5.8 \mathrm{~m},-10.4 \mathrm{~m},-14.0 \mathrm{~m}$ and $-22.0 \mathrm{~m}$ ) in the UK. Dyer (1975) reported a series of terraces in the Solent, while D'Olier mapped a series of submerged Thames terraces in the southern North Sea (Bridgland 2002: 29-30). 
Perhaps unsurprisingly (reflecting relatively shallow water depths and the locations of seismic profiling surveys and coring) many of these terrace sequences have been documented in the immediate offshore areas. In these areas they are typically associated with the buried channel extensions of estuarine lower reaches of modern rivers. Moreover, it seems extremely likely that in different regions of the non-glaciated maritime zone (i.e. the English Channel and the southern North Sea), terrace development varied in pattern and extent, reflecting marine influences and uplift rate differences. Antoine et al. (2003: 240) noted the major changes in the bedrock gradient profiles between the lower Somme and the submarine area, and suggested that these were the result of differential uplift rates. While the relatively high rates in the lower valley are associated with a stepped terrace system and high gradients, the lower uplift rates and 'relative subsidence' in the submerged area are linked with stacked alluvial sequences and a lower gradient. Bridgland (2002: 30 \& Fig. 5) has also reviewed similar evidence for the Rhine system.

Vertical, stepped terrace sequences with altitudinally-separated units would offer potential for long profile correlations with the terrestrial terraces (e.g. Bridgland 2002: Fig. 3). Their absence in particular parts of the maritime zone therefore creates obvious difficulties for the development of robust geochronologies (whether absolute or relative), even before considering the potential problems of lateral re-working. There is clearly a need for further studies highlighting both the nature of, and potential for, long-term terrace development in the southern North Sea and English Channel zones, and the development of direct OSL dating of submerged deposits.

In summary then, there is a clear need to assess, on an area by area basis for the maritime zone, firstly whether terrace deposits would actually have formed, and secondly whether they would have subsequently been preserved over the long time-span of the Middle and Late Pleistocene (after Westley et al. 2004: 136).

\subsection{Sampling problems}

Secondly, how will any Lower Palaeolithic resource be sampled from the maritime zone? It is apparent that the only practical collecting and sampling strategies at the current time are those developed through collaboration with the fishing industry (Glimmerveen et al. 2004; Verhart 2004; van Kolfschoten \& van Essen 2004), aggregates companies (Flemming 2004), and dredging operations relating to the maintenance of navigation routes (van Kolfschoten \& van Essen 2004). Current information regarding the location and context of material is often limited and of relatively poor spatial resolution, although in some instances (e.g. Glimmerveen et al. 2004; Mol et al. 2003) GPS co-ordinates have provided exact localities for retrieved materials. Overall these sampling activities are clearly broad scale, and it appears likely that they will remain so for the foreseeable future. It is perhaps worth noting here however that evaluation of areas of archaeological potential (maybe based on previous fossil finds and/or the location of key sedimentary deposits) could potentially utilise a logistic dredging approach, in advance of commercial dredging activities. Samples could then be specifically examined for possible archaeological content. 
In the meantime the current, broad-scale sampling strategies have clear implications for data quality and the identification of interpretative models and potential questions. Yet as indicated above such sampling strategies and collection activities can be integrated with a palimpsest data resource and appropriate-scale methodologies to potentially extract valuable archaeological data. As discussed throughout this paper, the first requirement is to consider the potential spatial and temporal scales of the available data and how it may be related to appropriate questions. It is apparent from the above discussions that data from particular regions is likely to be both heavily time- and space-averaged. This reflects fluvial re-working of artefacts during low sea level stands, possible marine reworking of sediments and artefacts during the high sea level stands (i.e. the transformation from secondary to tertiary contexts), and the nature of the current sampling strategies. Nonetheless, two potential data patterns are suggested here as initial foci for future research questions (Table 2):

- Variations between river systems (e.g. the offshore Arun or Seine) and/or regions (e.g. the southern North Sea and the central English Channel) in terms of quantities of material culture. These patterns could be valuably related to onshore regional patterns (e.g. differences in material quantities between the Thames Valley and the Solent River Basin, or the Somme and the Rhine Valleys) to consider wider-scale questions of hominin colonisation patterns in north-western Europe during the Lower Palaeolithic.

- Variations between river systems and/or regions in terms of variations in material culture. For example testing the apparent claims by White \& Schreve (2000: 1520) that Acheulean (handaxe) groups may have entered Britain from northern France, while Clactonian (core and flake technology) groups may have entered Britain from Germany and central Europe.

- It is also worth considering that appropriately large-scale questions might even highlight archaeological potential in the re-worked tertiary context resource. This would obviously be of greater likelihood if any resources were located in the vicinity of the secondary contexts from which the sediments were re-worked (Westley et al. 2004: 144).

\section{Conclusions}

In conclusion, the extensive faunal material and much more limited lithic artefact archive from the southern North Sea and the English Channel, combined with other recent research, has begun to promote the idea of a Palaeolithic archaeological potential for the maritime zone in north-western Europe. Indications from very occasional artefact finds and inshore mapping suggest that Pleistocene fluvial terraces may extend offshore in places. Moreover, the terrestrial Lower Palaeolithic record for north-western Europe indicates to us that despite data re-working there is still valuable evidence in the secondary context archaeological resources of fluvial landscapes. It is therefore suggested here that offshore terraces may be amenable to an application of assessment and analytical frameworks similar to those applied to terrestrial deposits. Equally however, it is clear that to fully access these data there is a need for robust geochronological and geoarchaeological models and appropriate mapping of archaeological questions against the variable spatio-temporal scales. Of particular importance is the need to: 
- Understand the geoarchaeological processes associated with terrace landform and deposit formation and modification in the maritime zone.

- Develop appropriate deposit (as opposed to site-based) modelling (Westley et al. 2004: 206) and archaeological sampling and dating strategies.

But by asking the right questions at the right spatio-temporal scales, we may be able to finally start to get to grips with a significant, understudied, and extensive landscape in the north-western fringes of the Acheulean world.

\section{Acknowledgements}

Parts of the research discussed in this paper were funded by English Heritage through the Aggregates Levy Sustainability Fund (The Archaeological Potential of Secondary Contexts, project no. 3361), and their support is gratefully acknowledged. The paper was initially presented at the Marine Geoarchaeology: Work in Progress meeting in November 2003, and the comments and feedback received from those present are gratefully acknowledged. Thanks are also due to $\mathrm{Dr}$ Jenni Chambers (including permission to reproduce the photographs in Figure 3), Dr Justin Dix, Kieran Westley, and an anonymous referee for their comments on earlier versions of this paper. All remaining ideas and errors are of course my own.

\section{References}

Agersnap-Larsen, N., Bulur, E., Bøtter-Jensen, L. \& McKeever, S.W.S. 2000. Use of the LMOSL technique for the detection of partial bleaching in quartz. Radiation Measurements 32: 419-425.

Allen, L.G. \& Gibbard, P.L. 1993. Pleistocene evolution of the Solent river of southern England. Quaternary Science Reviews 12: 503-528.

Antoine, P., Coutard, J-P., Gibbard, P., Hallegouet, B., Lautridou, J-P. \& Ozouf, J-C. 2003. The Pleistocene rivers of the English Channel region. Journal of Quaternary Science 18(3-4): 227-243.

Ashton, N.M., Lewis, S.G. \& Parfitt, S.A. 1998. Excavations at the Lower Palaeolithic Site of East Farm, Barnham, Suffolk 1989-1994. British Museum Occasional Paper No. 125. London: British Museum.

Ashton, N. \& Lewis, S. 2002. Deserted Britain: Declining Populations in the British Late Middle Pleistocene. Antiquity 76: 388-396.

Ashton, N.M., Lewis, S.G., Parfitt, S.A. \& White, M.J. 2006. Riparian landscapes and human habitat preferences during the Hoxnian (MIS 11) Interglacial. Journal of Quaternary Science 21(5): 497-505.

Bailey, R.M. 2003. Paper I: The use of measurement-time dependent single-aliquot equivalentdose estimates from quartz in the identification of incomplete signal resetting. Radiation Measurements 37: 673-683.

Bailey, R.M., Singarayer, J.S., Ward, S. \& Stokes, S. 2003. Identification of partial resetting using $\mathrm{D}_{\mathrm{e}}$ as a function of illumination time. Radiation Measurements 37: 511-518.

Bateman, M.D., Frederick, C.D., Jaiswal, M.K. \& Singhvi, A.K. 2003. Investigations into the potential effects of pedoturbation on luminescence dating. Quaternary Science Reviews 22: $1169-1176$.

Bates, M.R. 2001. The meeting of the waters: raised beaches and river gravels of the Sussex Coastal Plain/Hampshire Basin. In F.F. Wenban-Smith \& R.T. Hosfield (eds.) Palaeolithic Archaeology of the Solent River: 27-45. Lithic Studies Society Occasional Paper 7. London: Lithic Studies Society. 
Bates, M.R., Keen, D.H. \& Lautridou, J-P. 2003. Pleistocene marine and periglacial deposits of the English Channel. Journal of Quaternary Science 18(3-4): 319-337.

Bates, M.R., Parfitt, S.A. \& Roberts, M.B. 1997. The chronology, palaeogeography and archaeological significance of the marine Quaternary record of the West Sussex Coastal Plain, Southern England. Quaternary Science Reviews 16: 1227-1252.

Bellamy, A.G. 1995. Extension of the British landmass: evidence from shelf sediment bodies in the English Channel. In R.C. Preece (ed.) Island Britain: a Quaternary Perspective: 47-62. Special Publication No. 96. Bath: Geological Society Publishing House.

Bosinski, G. 1995. The earliest occupation of Europe: Western Central Europe. In W. Roebroeks \& T. van Kolfschoten (eds.) The Earliest Occupation of Europe. Proceedings of the European Science Foundation Workshop at Tautavel (France) 1993: 103-128. Leiden: Leiden University Press.

Breuil, H. 1939. The Pleistocene succession in the Somme Valley. Proceedings of the Prehistoric Society 5: 33-38.

Breuil, H. \& Koslowski, L. 1931. Etudes de stratigraphie paléolithique dans le nord de la France, la Belgique et l'Angleterre: la vallée de la Somme. L'Anthropologie 41: 449-488.

Breuil, H. \& Koslowski, L. 1932. Etudes de stratigraphie paléolithique dans le nord de la France, la Belgique et l'Angleterre: V — Basse terrasse de la Somme. L'Anthropologie 42: 27-47 \& 291-314.

Breuil, H. \& Koslowski, L. 1934. Etudes de stratigraphie paléolithique dans le nord de la France, la Belgique et l'Angleterre: la Belgique. L'Anthropologie 44: 249-290.

Briant, R.M., Bates, M.R., Schwenninger, J-L. \& Wenban-Smith, F. 2006. An optically stimulated luminescence dated Middle to Late Pleistocene fluvial sequence from the western Solent Basin, southern England. Journal of Quaternary Science 21(5): 507-523.

Bridgland, D.R. 1985. Uniclinal shifting: A speculative reappraisal based on terrace distribution in the London Basin. Quaternary Newsletter 47: 26-33.

Bridgland, D.R. 1994. Quaternary of the Thames. Geological Conservation Review Series 7. London: Chapman \& Hall.

Bridgland, D.R. 1998. The Pleistocene history and early human occupation of the River Thames valley. In N. Ashton, F. Healy \& Pettitt, P. (eds.) Stone Age Archaeology: Essays in honour of John Wymer: 29-37. Lithic Studies Society Occasional Paper 6. Oxford: Oxbow Books.

Bridgland, D.R. 2000. River terrace systems in north-west Europe: an archive of environmental change, uplift and early human occupation. Quaternary Science Review 19: 1293-1303.

Bridgland, D.R. 2001. The Pleistocene Evolution and Palaeolithic Occupation of the Solent River. In F.F. Wenban-Smith \& R.T. Hosfield (eds.) Palaeolithic Archaeology of the Solent River: 15-25. Lithic Studies Society Occasional Paper 7. London: Lithic Studies Society.

Bridgland, D.R. 2002. Fluvial deposition on periodically emergent shelves in the Quaternary: example records for the shelf around Britain. Quaternary International 92: 25-34.

Bridgland, D.R., Maddy, D. \& Bates, M.R. 2004. River terrace sequences: templates for Quaternary geochronology and marine-terrestrial correlation. Journal of Quaternary Science 19(2): 203-218.

Bridgland, D.R., Antoine, P., Limondin-Lozouet, N., Santisteban, J.I., Westaway, R. \& White, M.J. 2006. The Palaeolithic occupation of Europe as revealed by evidence from the rivers: data from IGCP 449. Journal of Quaternary Science 21(5): 437-455.

Bridgland, D.R. \& Schreve, D. 2001. River terrace formation in synchrony with long-term climatic fluctuation: supporting mammalian evidence from southern Britain. In D. Maddy, M. Macklin \& Woodward, J. (eds.) River Basin Sediments Systems: Archives of Environmental Change: 229-248. Rotterdam: Balkema.

Cameron, T.D.J., Laban, C. \& Schüttenhelm, R.T.E. 1984. Quaternary geology. BGS/RGD, Sheet $52^{\circ} \mathrm{N}-2^{\circ} \mathrm{E}$, Flemish Bight 1: 250,000 Series. 
Cameron, T.D.J., Laban, C. \& Schüttenhelm, R.T.E. 1989a. Upper Pliocene and Lower Pleistocene stratigraphy in the Southern Bight of the North Sea. In J.P. Henriet, G. de Moor \& M. de Batist (eds.) The Quaternary and Tertiary Geology of the Southern Bight, North Sea: 97-110. Ghent: BEON.

Cameron, T.D.J., Laban, C. \& Schüttenhelm, R.T.E. 1989b. Middle and Upper Pleistocene and Holocene stratigraphy in the southern North Sea between $52^{\circ}$ and $54^{\circ} \mathrm{N}, 2^{\circ}$ to $4^{\circ} \mathrm{E}$. In J.P. Henriet, G. de Moor \& M. de Batist (eds.) The Quaternary and Tertiary Geology of the Southern Bight, North Sea: 119-135. Ghent: BEON.

Cameron, T.D.J., Crosby, A., Balson, P.S., Jeffery, D.H., Lott, G.K., Bulat, J. \& Harrison, D.J. 1992. The Geology of the Southern North Sea. London: HMSO.

Chambers, J.C. 2004. The spatial modelling of Palaeolithic secondary context assemblages: case studies from the Solent River System and Axe River Valley, UK. Unpublished PhD Thesis, University of Southampton.

Chambers, J.C. 2005a. Like a Rolling Stone? The Identification of Fluvial Transportation Damage Signatures on Secondary Context Bifaces. Lithics: The Newsletter of the Lithic Studies Society 24: 66-77.

Chambers, J.C. 2005b. River gravels and handaxes: new experiments in site formation, stone tool transportation and transformation. In M. Fansa (ed.) Experimentelle Archäologie in Europa, Bilanz 2004, Heft 3: 25-41. Oldenburg: Isensee Verlag.

Coles, B.J. 1998. Doggerland: a speculative survey. Proceedings of the Prehistoric Society 64: 45-81.

Conway, B., McNabb, J. \& Ashton, N.M. (eds.) 1996. Excavations at Barnfield Pit, Swanscombe 1968-1972. British Museum Occasional Paper No. 94. London: British Museum.

Duller, G.A.T, Bøtter-Jensen, L., Kohsiek, P. \& Murray, A.S. 1999. A high sensitivity optically stimulated luminescence scanning system for measurement of single sand-sized grains. Radiation Protection Dosimetry 84: 325-330.

Durrance, E.M. 1969. The Buried Channels of the Exe. Geological Magazine 106(2): 174-189.

Durrance, E.M. 1974. Gradients of Buried Channels in Devon. Proceedings of the Ussher Society 3(1): 111-119.

Drees, M. 1986. Kritische kanttekeningen bij de naam 'Zwarte botten fauna'. Cranium 3(2): 103120.

Dyer, K.R. 1975. The buried channels of the 'Solent River', southern England. Proceedings of the Geologists Association 86(2): 239-245.

Flemming, N.C. 1998. Archaeological evidence for vertical movement on the continental shelf during the Palaeolithic, Neolithic and Bronze Age periods. In I. Stewart \& C. Vita-Finzi (eds.) Coastal Tectonics: 129-146. Geological Society Special Publications 146. London: Geological Society.

Flemming, N.C. 2002. Archaeology. Strategic Environmental Assessment Document 3. London: Department of Trade and Industry.

Flemming, N.C. 2004. Summary of discussions and drafting groups. In N. Flemming (ed.) Submarine prehistoric archaeology of the North Sea: 113-118. CBA Research Report 141. York: English Heritage/Council for British Archaeology.

Fischer, A. 2004. Submerged Stone Age - Danish examples and North Sea potential. In N. Flemming (ed.) Submarine prehistoric archaeology of the North Sea: 23-36. CBA Research Report 141. York: English Heritage/Council for British Archaeology.

Galbraith, R.F., Roberts, R.G. \& Yoshida, H. 2005. Error variation in OSL palaeodose estimates from single aliquots of quartz: a factorial experiment. Radiation Measurements 39: 289-307.

Gamble, C.S. 1996. Hominid Behaviour in the Middle Pleistocene: an English Perspective. In C.S. Gamble \& A.J. Lawson (eds.) The English Palaeolithic Reviewed: 61-71. Salisbury: Wessex Archaeology Ltd. 
Gibbard, P.L. \& Lautridou, J-P. 2003. The Quaternary history of the English Channel: an introduction. Journal of Quaternary Science 18(3-4): 195-199.

Gibbard, P.L. \& Lewin, J. 2002. Climate and related controls on interglacial fluvial sedimentation in lowland Britain. Sedimentary Geology 151: 187-210.

Glimmerveen, J., Mol, D., Post, K., Reumer, J.W.F., van der Plicht, H., de Vos, J., van Geel, B., van Reenen, G. \& Pals, J.P. 2004. The North Sea project: the first palaeontological, palynological, and archaeological results. In N. Flemming (ed.) Submarine prehistoric archaeology of the North Sea: 43-52. CBA Research Report 141. York: English Heritage/Council for British Archaeology.

Green, H.S. 1984. Pontnewydd Cave: a lower Palaeolithic hominid site in Wales: the first report. Cardiff: National Museum of Wales.

Gupta, S. 2004. Submerged Palaeo-Arun and Solent Rivers: Reconstruction of Prehistoric Landscapes. English Heritage Archive Report (Project No. 3543 \& 3277). London: English Heritage.

Hack, B. 2000. Rainbow Bar: some observations and thoughts. Lithics: The Newsletter of the Lithic Studies Society 21: 36-44.

Hamblin, R.J.O., Crosby, A., Balson, P.S., Chadwick, R.A., Penn, I.E. \& Arthur, M.J. 1992. The Geology of the English Channel. London: HMSO.

Hosfield, R.T. 2001. The Lower Palaeolithic of the Solent: site formation and interpretive frameworks. In F.F. Wenban-Smith \& R.T. Hosfield (eds.) Palaeolithic Archaeology of the Solent River: 85-97. Lithic Studies Society Occasional Paper 7. London: Lithic Studies Society.

Hosfield, R.T. 2005. Individuals among palimpsest data: fluvial landscapes in Southern England. In C.S. Gamble \& M. Porr (eds.) The Individual Hominid in Context: Archaeological investigations of Lower and Middle Palaeolithic landscapes, locales and artefacts: 220-243. Abingdon: Routledge (Taylor \& Francis).

Hosfield, R.T. \& Chambers, J.C. 2002. The Lower Palaeolithic site of Broom: geoarchaeological implications of optical dating. Lithics: The Newsletter of the Lithic Studies Society 23: 33-42.

Hosfield, R.T. \& Chambers, J.C. 2004. The Archaeological Potential of Secondary Contexts. English Heritage Archive Report (Project No. 3361). London: English Heritage.

Hosfield, R.T. \& Chambers, J.C. 2005. Pleistocene geochronologies for fluvial sedimentary sequences: an archaeologist's perspective. Journal of Quaternary Science 20(3): 285-296.

Howard, A.J. \& Macklin, M.G. 1999. A generic morphological approach to archaeological interpretation and prospection in British river valleys: a guide for archaeologists investigating Holocene landscapes. Antiquity 73: 527-541.

Kaufman, D.S. \& Manley, W.F. 1998. A New Procedure for Determining DL Amino Acid Ratios in Fossils Using Reverse Phase Liquid Chromatography. Quaternary Science Reviews 17: 987-1000.

Lericolais, G., Auffret, J-P. \& Bourillet, J-F. 2003. The Quaternary Channel River: seismic stratigraphy of its palaeo-valleys and deeps. Journal of Quaternary Science 18(3-4): 245-260.

Lewis, S.G. \& Maddy, D. 1999. Description and Analysis of Quaternary Fluvial Sediments: a case study from the Upper River Thames, UK. In A.P. Jones, M.E. Tucker \& J.K. Hart (eds.) The Description and Analysis of Quaternary Stratigraphic Field Sections: 111-135. London: Quaternary Research Association.

Long, D., Graham, C. \& Stevenson, A. 2004. Existing resources of acoustic and sedimentary sample data for analysing the landscape for human occupation in the North Sea. In N. Flemming (ed.) Submarine prehistoric archaeology of the North Sea: 99-101. CBA Research Report 141. York: English Heritage/Council for British Archaeology.

Maddy, D. \& Bridgland, D.R. 2000. Accelerated uplift resulting from Anglian glacioisostatic rebound in the Middle Thames valley, UK? Evidence from the river terrace record. Quaternary Science Review 19: 1581-1588. 
Maddy, D., Bridgland, D.R. \& Westaway, R. 2001. Uplift-driven valley incision and climatecontrolled river terrace development in the Thames Valley, UK. Quaternary International 79: 23-36.

Marshall, G.D. 2001. The Broom pits: a review of research and a pilot study of two Acheulean biface assemblages. In F.F. Wenban-Smith \& R.T. Hosfield (eds.) Palaeolithic Archaeology of the Solent River: 77-84. Lithic Studies Society Occasional Paper 7. London: Lithic Studies Society.

Mol, D., Post, K., Reumer, J.W.F., de Vos, J. \& Laban, C. 2003. Het Gat: preliminary note on a Bavelian fauna from the North Sea with possibly two mammal species. Deinsea 9: 253-266.

Murray, A.S. \& Olley, J.M. 2002. Precision and accuracy in the Optically Stimulated Luminescence dating of sedimentary quartz: a status review. Geochronometria 21: 1-16.

Murray, A.S. \& Wintle, A.G. 2000. Luminescence dating of quartz using an improved singlealiquot regenerative-dose protocol. Radiation Measurements 32: 57-73.

Parfitt, S.A., Barendregt, R.W., Breda, M., Candy, I., Collins, M.J., Coope, R.G., Durbridge, P., Field, M.H., Lee, J.R., Lister, A.M., Mutch, R., Penkman, K.E.H., Preece, R.C., Rose, J., Stringer, C.B., Symmons, R., Whittaker, J.E., Wymer, J.J. \& Stuart, A.J. 2005. The earliest record of human activity in northern Europe. Nature 438: 1008-1112.

Penkman, K.E.H. 2005. Amino acid geochronology: a closed system approach to test and refine the UK model. Unpublished $\mathrm{PhD}$ thesis, University of Newcastle.

Reynaud, J-Y., Tessier, B., Auffret, J-P., Berné, S., De Batist, M., Marsset, T. \& Walker, P. 2003. The offshore Quaternary sediment bodies of the English Channel and its Western Approaches. Journal of Quaternary Science 18(3-4): 361-371.

Roberts, M.B., Gamble, C.S. \& Bridgland, D.R. 1995. The earliest occupation of Europe: the British Isles. In W. Roebroeks \& T. van Kolfschoten (eds.) The Earliest Occupation of Europe. Proceedings of the European Science Foundation Workshop at Tautavel (France) 1993: 165-191. Leiden: Leiden University Press.

Roberts, M.B. \& Parfitt, S.A. 1998. The Middle Pleistocene Hominid Site at Boxgrove, West Sussex, UK. English Heritage Monograph Series. London: English Heritage.

Roe, D.A. 1968. British Lower and Middle Palaeolithic handaxe groups. Proceedings of the Prehistoric Society 34: 1-81.

Roe, D.A. 1981. The Lower and Middle Palaeolithic Periods in Britain. London: Routledge \& Kegan Paul.

Roe, D.A. 2001. Some Earlier Palaeolithic finds-spots of interest in the Solent region. In F.F. Wenban-Smith \& R.T. Hosfield (eds.) Palaeolithic Archaeology of the Solent River: 47-56. Lithic Studies Society Occasional Paper 7. London: Lithic Studies Society.

Roebroeks, W. 2005. Life on the Costa del Cromer. Nature 438: 921-922.

Rose, J., Turner, C., Coope, G.R. \& Bryan, M.D. 1980. Channel changes in a lowland river catchment over the last 13,000 years. In R.A. Cullingford, D.A. Davidson \& J. Lewin (eds.) Timescales in Geomorphology: 159-175. Chichester: John Wiley \& Sons Ltd.

Schreve, D.C. 2001. Differentiation of the British late Middle Pleistocene interglacials: the evidence from mammalian biostratigraphy. Quaternary Science Reviews 20: 1693-1705.

Schreve, D.C. \& Bridgland, D.R. 2002. Correlation of English and German Middle Pleistocene fluvial sequences based on mammalian biostratigraphy. Netherlands Journal of Geosciences 81(3-4): 357-373.

Stern, N. 1993. The Structure of the Lower Pleistocene Archaeological Record. Current Anthropology 43(3): 201-224.

Stern, N. 1994. The implications of time-averaging for reconstructing the land-use patterns of early tool-using hominids. In J.S. Oliver, N.E. Sikes \& K.M. Stewart (eds.) Early Hominid Behavioural Ecology: 89-105. London: Academic Press Limited. 
Stern, N. 2004. Early Hominin Activity Traces at FxJj43, a One and a Half Million Year Old Locality in the Koobi Fora Formation, in Northern Kenya: a Field Report. Proceedings of the Prehistoric Society 70: 233-258.

Stokes, S., Ingram, S., Aitken, M.J., Sirocko, F. \& Anderson, R. 2003. Alternative chronologies for late Quaternary (Last Interglacial-Holocene) deep sea sediments via optical dating of silt-sized quartz. Quaternary Science Reviews 22: 925-941.

Sykes, G.A., Collins, M.J. \& Walton, D.I. 1995. The significance of a geochemically isolated (intra-crystalline) organic fraction within biominerals. Organic Geochemistry 23: 1059-1066.

Thomsen, K.J., Murray, A.S. \& Bøtter-Jensen, L. 2005. Sources of variability in OSL measurements using single grains of quartz. Radiation Measurements 39: 47-61.

Toms, P.S. 2002. The acquisition of equivalent dose estimates from natural sedimentary quartz using optically stimulated luminescence. Unpublished $\mathrm{PhD}$ thesis, University of London.

Toms, P., Hosfield, R.T., Chambers, J.C., Green, C.P. \& Marshall, P. 2005. Optical dating of the Broom Palaeolithic sites, Devon \& Dorset. Centre for Archaeology Report 16/2005. London: English Heritage.

Tuffreau, A. \& Antoine, P. 1995. The earliest occupation of Europe: Continental Northwestern Europe. In W. Roebroeks \& T. van Kolfschoten (eds.) The Earliest Occupation of Europe: Proceedings of the European Science Foundation Workshop at Tautavel (France), 1993: 147163. Leiden: University of Leiden.

Tuffreau, A., Lamotte, A. \& Marcy, J-L. 1997. Land-use and site function in Acheulean complexes of the Somme Valley. World Archaeology 29(2): 225-241.

Van Huissteden, J., Gibbard, P.L. \& Briant, R.M. 2001. Periglacial fluvial systems in northwest Europe during marine isotope stages 4 and 3. Quaternary International 79: 75-88.

van Kolfschoten, T. \& van Essen, H. 2004. Palaeozoological heritage from the bottom of the North Sea. In N. Flemming (ed.) Submarine prehistoric archaeology of the North Sea: 70-80. CBA Research Report 141. York: English Heritage/Council for British Archaeology.

Vandenberghe, J. 1993. Changing fluvial processes under changing periglacial conditions. Zeitschrift für Geomorphologie, Supplement Band 88: 17-28.

Vandenberghe, J. 1995. Timescales, Climate and River Development. Quaternary Science Reviews 14: 631-638.

Vandenberghe, J. 2002. The relation between climate and river processes, landforms and deposits during the Quaternary. Quaternary International 91: 17-23.

Vandenberghe, J. 2003. Climate forcing of fluvial system development: an evolution of ideas. Quaternary Science Reviews 22: 2053-2060.

Velegrakis, A., Dix, J.K. \& Collins, M.B. 1999. Late Quaternary evolution of the upper reaches of the Solent River, southern England, based upon marine geophysical evidence. Journal of the Geological Society, London 156: 73-87.

Verhart, L.M.B. 2004. The implications of prehistoric finds on and off the Dutch coast. In N. Flemming (ed.) Submarine prehistoric archaeology of the North Sea: 57-61. CBA Research Report 141. York: English Heritage/Council for British Archaeology.

Wallinga, J., Murray, A.S., Duller, G.A.T. \& Tornqvist, T.E. 2001. Testing optically stimulated luminescence dating of sand-sized quartz and feldspar from fluvial deposits. Earth and Planetary Science Letters 193: 617-630.

Wallinga, J. 2002. Optically stimulated luminescence dating of fluvial deposits: a review. Boreas 31: 303-322.

Wenban-Smith, F.F. 2003. Palaeolithic and Mesolithic Archaeology on the Sea-bed: Marine Aggregate Dredging and the Historic Environment. Salisbury: Wessex Archaeology.

Werz, B. \& Flemming, N.C. 2001. Discovery of the world's oldest underwater finds in Table Bay demonstrates preservation of hominid artefacts on the continental shelf. South African Journal of Science 97: 183-185. 
Wessex Archaeology. 1993a. The Southern Rivers Palaeolithic Project: Report No. 1, 19911992. The Upper Thames Valley, the Kennett Valley and the Upper Solent Drainage System. Salisbury: Wessex Archaeology \& English Heritage.

Wessex Archaeology. 1993b. The Southern Rivers Palaeolithic Project Report No. 2. 1992-1993. The South West and South of the Thames. Salisbury: Wessex Archaeology \& English Heritage.

Wessex Archaeology. 1994. The Southern Rivers Palaeolithic Project. Report No. 3. 1993-1994. The Sussex Raised Beaches and the Bristol Avon. Salisbury: Wessex Archaeology \& English Heritage.

Wessex Archaeology. 1996a. The Welsh Lower Palaeolithic Survey. 1996. Salisbury: Wessex Archaeology \& CADW.

Wessex Archaeology. 1996b. The English Rivers Palaeolithic Project. Report No. 1. 1994-1995. The Thames Valley and the Warwickshire Avon. Salisbury: Wessex Archaeology \& English Heritage.

Wessex Archaeology. 1996c. The English Rivers Palaeolithic Project. Report No. 2. 1995-1996. The Great Ouse Drainage and the Yorkshire and Lincolnshire Wolds. Salisbury: Wessex Archaeology \& English Heritage.

Wessex Archaeology. 1997. The English Rivers Palaeolithic Project. Report No. 3. 1996-1997. East Anglia Rivers and the Trent Drainage. Salisbury: Wessex Archaeology \& English Heritage.

Wessex Archaeology. 2004. Artefacts from the Sea: Year Two Report (Revised). Unpublished Report.

Westley, K., Dix, J. \& Quinn, R. 2004. A Re-assessment of the Archaeological Potential of Continental Shelves. English Heritage Archive Report (Project No. 3362). London: English Heritage.

White, M.J. 1998a. On the significance of Acheulean biface variability in southern Britain. Proceedings of the Prehistoric Society 64: 15-44

White, M.J. 1998b. Twisted Ovate Bifaces in the British Lower Palaeolithic: Some Observations and Implications. In N. Ashton, F. Healy \& P. Pettitt (eds.) Stone Age Archaeology: Essays in Honour of John Wymer: 98-104. Oxbow Monograph 102 \& Lithic Studies Society Occasional Paper 6. London: Oxbow Books.

White, M.J. \& Schreve, D.C. 2000. Island Britain - Peninsula Britain: Palaeogeography, Colonisation and the Lower Palaeolithic Settlement of the British Isles. Proceedings of the Prehistoric Society 66: 1-28.

White, M., Scott, B. \& Ashton, N. 2006. The Early Middle Palaeolithic in Britain: archaeology, settlement history and human behaviour. Journal of Quaternary Science 21(5): 525-541.

Wymer, J.J. 1968. Lower Palaeolithic Archaeology in Britain, as Represented by the Thames Valley. London: John Baker.

Wymer, J.J. 1974. Clactonian and Acheulean industries in Britain: their chronology and significance. Proceedings of the Geologists Association 85: 391-421.

Wymer, J.J. 1999. The Lower Palaeolithic Occupation of Britain. London: Wessex Archaeology $\&$ English Heritage.

Yoshida, H., Roberts, R.G., Olley, J.M., Laslett, J.M. \& Galbraith, R.F. 2000. Extending the age range of optical dating using single 'supergrains' of quartz. Radiation Measurements 32: 439446. 